\title{
Sylvie Triaire, Paysager la mélancolie: rythmes flaubertiens pour un saint
}

\author{
Isabella Giovinazzo
}

\section{(2) OpenEdition \\ 1 Journals}

\section{Edizione digitale}

URL: https://journals.openedition.org/studifrancesi/38017

DOI: 10.4000/studifrancesi.38017

ISSN: 2421-5856

Editore

Rosenberg \& Sellier

\section{Edizione cartacea}

Data di pubblicazione: 15 décembre 2004

Paginazione: 635

ISSN: 0039-2944

\section{Notizia bibliografica digitale}

Isabella Giovinazzo, «Sylvie Triaire, Paysager la mélancolie: rythmes flaubertiens pour un saint», Studi Francesi [Online], 144 (XLVIII | III) | 2004, online dal 30 novembre 2015, consultato il 08 mai 2021. URL: http://journals.openedition.org/studifrancesi/38017 ; DOI: https://doi.org/10.4000/studifrancesi. 38017

Questo documento è stato generato automaticamente il 8 mai 2021.

\section{(c)}

Studi Francesi è distribuita con Licenza Creative Commons Attribuzione - Non commerciale - Non opere derivate 4.0 Internazionale. 


\title{
Sylvie Triaire, Paysager la mélancolie: rythmes flaubertiens pour un saint
}

\author{
Isabella Giovinazzo
}

\section{NOTIZIA}

SYLVIE TRIAIRE, Paysager la mélancolie: rythmes flaubertiens pour un saint, «Romantisme» $\mathrm{n}$. 117 (III Trim. 2002) pp. 58-75.

1 Partendo dal rapporto tra malinconia e creazione letteraria e dall'analisi delle modalità attraverso cui si costituiscono i paesaggi correlati a tale stato d'animo, l'A. prende in esame i paesaggi presenti in La légende de Saint Julien l'Hospitalier mettendoli in relazione alle modalità stesse della scrittura flaubertiana e alla sua dinamica interna. Si tratta infatti di scenari instabili e vaghi, non completamente definiti, che si ricollegano direttamente allo stile dell'autore, alle tensione e alle oscillazioni della scrittura, ovvero caratteristiche generate dalla tonalità emotiva del personaggio, che peraltro coincide con quella dell'autore stesso. 